\title{
BATASAN KEWENANGAN MENGADILI PENGADILAN UMUM DALAM PENYELESAIAN SENGKETA PERBUATAN MELAWAN HUKUM YANG MELIBATKAN BADAN NEGARA ATAU PEJABAT PEMERINTAH
}

\author{
(Ditinjau dari Peraturan Mahkamah Agung Nomor 2 Tahun 2019)
}

\author{
Hairul Maksum \\ Fakultas Hukum Universitas Gunung Rinjani \\ e-mail : hairulmaksum71@gmail.com
}

\section{Info Artikel}

Sejarah Artikel :

Diterima Juni 2020

Disetujui September 2020

Publikasi November 2020

\section{Keyword:}

Limitation, Judicial

Authority, Supreme Court

Regulation

\begin{abstract}
Alostract
This study aims to determine the limits of the authority to adjudicate between general and state administrative courts. This type of research is Normative Legal Research, $d$ at studying the statutory regulations and legal concepts, in this case regulating court proceedings. The method used in this study is to use a statute approach and a conceptual approach. The legal materials used in the study are library legal materials, consisting of primary legal materials, secondary legal materials and tertiary legal materials. The approach method used is statutory and conceptual. The legal materials used are literature, consisting of primary, secondary and tertiary legal materials. The results of the study, 1) the absolute competence between the General Court and the State Administrative Court has been regulated in the Judicial Power Act and the Supreme Court Law, but it seems biased because it does not specifically mention the limits of authority. 2). The Supreme Court has issued Supreme Court Regulation No.2 of 2019 concerning Guidelines for Resolving Disputes on Government Actions and the Authority to Adjudicate Unlawful Acts by Government Agencies and / or Officials (Onrechmatige Overheidsdaad).
\end{abstract}

\section{Abstrak}

Penelitian ini bertujuan untuk mengetahui batasan kewenangan mengadili antara peradilan umum dan peradilan tata usaha negara. Jenis penelitian hukum normatif, mengkaji peraturan perundang-undangan dan konsep-konsep hukum yang mengatur tata cara beracara di pengadilan. Metode pendekatan yang digunakan perundang-undangan dan konseptual. Bahan hukum yang digunakan adalah kepustakaan, terdiri dari bahan hukum primer, sekunder dan tersier. Hasil penelitian, 1) kompetensi absolut antara Peradilan Umum dan peradilan TUN telah diatur dalam Undang-Undang Kekuasaan Kehakiman dan UndangUndang Mahkamah Agung, tetapi terkesan masih bias karena tidak menyebutkan secara spesifik batasan-batasan kewenangan. 2). Mahkamah Agung telah mengeluarkan Peraturan Mahkamah Agung Nomor 2 Tahun 2019 tentang Pedoman Penyelesaian sengketa Tindakan Pemerintah dan Kewenangan Mengadili Perbuatan Melanggar Hukum oleh Badan dan/atau Pejabat Pemerintahan (Onrechmatige Overheidsdaad). 


\section{A. PENDAhuluan}

Penyelesaian sengketa di pengadilan merupakan salah satu cara yang paling diminati oleh sebagian masyarakat disamping adanya cara penyelesaian sengketa di luar pengadilan, dikarenakan pengadilan merupakan suatu lembaga yang dipercaya dapat memberikan solusi yang bersifat mengikat bagi para pencari keadilan berkaitan dengan masalah yang sedang dihadapi, namun disisi lain sebagian masyarakat pencari keadilan merasa hakhaknya dilanggar apabila terjadi kesalahan kewenangan mengadili dari lembaga pengadilan tersebut terhadap sengketa yang sedang diadilinya.

Sejauh ini berdasarkan pengalaman penulis sebagai praktisi hukum dan juga sebagai akademisi yang mengajar Ilmu Hukum, dalam menyoroti kewenangan mengadili lembaga pengadilan tersebut ternyata kejadian dilapangan dunia peradilan terkadang dalam beberapa kasus hukum sepertinya ada terjadi abuse of power (melampui batas kewenangan) dari lembaga pengadilan yang telah digariskan oleh Undang-Undang terkait Kompetensi Absolut lembaga pengadilan dalam mengadili sebuah perkara, terutama apabila terjadi perkara Perbuatan Melawan Hukum yang melibatkan Badan Negara atau Pejabat Pemerintah (onrechtmatige overheidsdaad). Contoh Kasus seperti BPN sebagai badan negara yang bergelut dalam bidang pendaftaran tanah (cadastere) atau Badan pembuat sertifikat hak atas tanah yang sering ditarik sebagai tergugat oleh penggugat di dalam perkara perdata terkait perbuatan melawan hukum, seperti dalam kasus terbitnya sertifikat ganda terhadap objek sengketa yang melibatkan Badan Pertanahan Nasional (BPN) tersebut, dalam praktik hukum acara di peradilan umum (Pengadilan Negeri) sebagai pengadilan tingkat pertama, ternyata Pengadilan negeri tetap saja dapat menerima dan mengadili sendiri perkara tersebut walaupun adanya eksepsi dari pihak tergugat terkait kewenangan mengadili.

Dalam beberapa teori hukum menyebutkan bahwa tindakan perbuatan melawan hukum yang melibatkan Badan Negara/Pejabat Pemerintah (onrechtmatige overheidsdaad)) seperti BPN merupakan kompetensi absolut Lapangan Pengadilan Tata Usaha Negara (PERATUN) mengadilinya bukan wewenang Lapangan peradilan Umum. Jenis kasus tersebut selalu membingungkan banyak pihak sehingga diperlukan ketegasan dalam mengaturnya.

Peraturan-peraturan yang mengatur tentang kewenangan mengadili tersebut sejauh ini dipandang terlalu umum dan terkesan tidak tegas sehingga pelaksanaan hukum acara di lapangan peradilan menjadi bias dan kurang diindahkan oleh Para Hakim. Untuk menghindari permasalahan biasnya pelaksanaan peraturan tersebut diperlukan peraturan yang bersifat khusus.

Dalam menyelesaikan perkara yang sedang diadili oleh lembaga pengadilan, kewenangan mengadili yang timbul dalam lingkungan peradilan tersebut pada dasarnya sudah mempunyai batasan yang telah digariskan oleh Undang-Undang, terutama tentang Undang-Undang Kekuasaan Kehakiman. Sengketa kewenangan mengadili antara Pengadilan yang satu dengan lembaga Pengadilan yang lain seyogyanya sedapat mungkin agar dapat dihindarkan agar masyarakat pencari keadilan benar-benar mendapatkan kepastian hukum dari setiap putusan yang telah diciptakan oleh hakim sebagai wakil tuhan berdasarkan yurisdiksi kekuasaan kehakiman yang digariskan oleh Undang-Undang kepadanya.

Berdasarkan pasal 24 ayat (1) UUD 1945 berbunyi "Kekuasaan Kehakiman merupakan kekuasaan yang merdeka untuk menyelenggarakan peradilan guna menegakkan hukum dan keadilan"." Mengenai kekuasaan kehakiman yang di

\footnotetext{
1 Republik Indonesia, Undang-Undang Dasar Negara Republik Indonesia Tahun 1945
} 
amanatkan oleh pasal 24 ayat (1) UUD 1945 tersebut dipertegas lagi dalam UndangUndang Nomor 48 Tahun 2009 tentang kekuasaan kehakiman terutama dalam Pasal 1 berbunyi "Kekuasaan Kehakiman adalah kekuasaan Negara yang merdeka untuk menjalankan peradilan guna menegakkan hukum dan keadilan berdasarkan Pancasilan dan Undang-undang Dasar Negara Republik Indonesia Tahun 1945, demi terselenggaranya Negara Hukum Republik indonesia".2

Bertitik tolak dari ketentuan yang telah digariskan oleh Konstitusi Negara UUD 1945 dan berdasarkan UU No. 48 Tahun 2009 tentang Kekuasaan Kehakiman, dapat disimpulkan bahwa kemerdekaan lembaga pengadilan sudah mutlak tidak dapat ditawartawar lagi dan tidak dapat dicampuradukkan antara kekuasaan Ekesekutif, Legislatif dan Yudikatif. Berdasarkan pasal 24 ayat (2) UUD 1945, dan berdasarkan pasal (2) juncto Pasal 10 ayat (2) UU No. 4 Tahun 2004 juncto Pasal (1) UU No. 48 Tahun 2009 tentang Kekuasaan Kehakiman tersebut, penyelenggaraan kekuasan Kehakiman oleh Mahkamah Agung (MA) dilakukan oleh badan peradilan yang berada dibawahnya dalam :

- Lingkungan Peradilan Umum;

- Lingkungan peradilan Agama;

- Lingkungan Peradilan militer;

- Lingkungan peradilan Tata Usaha Negara;

Dari masing-masing lingkungan peradilan tersebut mempunyai kewenangan mengadili secara absolut dalam mengadili suatu perkara tertentu yang mutlak menjadi yurisdiksinya, artinya bahwa lingkungan peradilan lain seharusnya tidak boleh mengadili tanpa kewewenangan yang pasti, apalagi merupakan termasuk yurisdiksi absolut suatu lingkungan peradilan tertentu. Misalnya Pengadilan Negeri merupakan Pengadilan Umum, tidak berwenang memeriksa dan

\footnotetext{
2 Republik Indonesia, Undang-Undang No.48 Tahun 2009 "tentang Kekuasaan Kehakiman"
}

mengadili perkara yang merupakan yurisdiksi absolut Pengadilan TUN yang berkaitan dengan kebijakan tata usaha negara. ${ }^{3}$ Apabila suatu ketika terjadi sengketa tentang kewenangan mengadili antara Lingkungan pengadilan yang satu dengan Lingkungan pengadilan yang lainnya, maka pada akhirnya Mahkamah Agung (MA) sebagai pengadilan tertinggi akan menggunakan kekuasaannya untuk mengadili dan menyelesaikan sengketa tersebut dalam tingkat Kasasi ataupun dalam tingkat Peninjauan Kembali (PK), dengan demikian kalau terus terjadi sengketa perkara kewenangan mengadili yang diajukan ke Mahakamah Agung oleh para pihak yang berperkara, maka penumpukan perkara di Mahkamah Agung (MA) sebagai pengadilan tingkat terakhir terkait sengketa tersebut tidak dapat terhindarkan, sehingga menimbulkan tidak terlaksananya azas peradilan yang diharapkan secara cepat dan sederhana serta biaya murah.

Untuk menghindari menumpuknya perkara di Mahakamah Agung (MA) berkaitan dengan kewenangan mengadili di Lingkungan Lembaga Pengadilan tersebut, maka Mahkamah Agung memandang perlu mengelurakan peraturan khusus tentang masalah tersebut yang bersifat Lex specialist, sehingga tercipta sistem hukum yang menjamin kepastian hukum dan azas peradilan cepat, sederhana dan biaya murah yang selalu di cita-citakan oleh setiap insan pencari keadilan.

Sesuai dengan pokok-pokok pikiran dalam penulisan ini, maka dapat ditarik beberapa permasalahan, diantaranya : Pertama, Bagaimanakah batasan kewenangan mengadili Pengadilan Umum dan Pengadilan Tata Usaha Negara (TUN) dalam sengketa Perbuatan Melawan Hukum?; Kedua, Bagaimanakah pengaturan kewenangan mengadili Pengadilan Negeri dan Pengadilan Tata Usaha Negara (TUN)

\footnotetext{
3 M. Yahya Harahap, Kekuasaan Mahkamah Agung, Pemeriksaan kasasi dan Peninjauan kembali Perkara Perdata, Hal. 215.
} 
apabila melibatkan Badan Negara atau Pejebat Pemerintah dalam perkara perbuatan melawan hukum Menurut PERMA No. 2 Tahun 2019 ?.

\section{B. METODELOGI PENELITIAN}

Penelitian ini merupakan penelitian Yuridis-Normatif. Dapat dijelaskan bahwa Penelitian yuridis (penelitian hukum) adalah suatu bentuk kegiatan ilmiah di bidang hukum yang di dalamnya menggunakan metode, sistematika serta sebuah pemikiranyang bersifat khusus untuk mengkaji undang-undang, dengan menggunakan analisis tertentu. Kemudian juga dalam kajian tersebut menganalisa fakta-fakta ketimpangan untuk diusahakan untuk diselesaikan permasalahan yang dihadapi. $^{4}$

Pendekatan yang digunakan adalah pendekatan perundang-undangan dengan permasalahan yang diteliti dan pendekatan konsep bertujuan untuk mengkaji pengertian hukum dari beberapa pendapat ahli hukum yang berkaitan dengan masalah yang diteliti. Sumber data yang digunakan dari bahan hukum primer dari UU Nomor 48 Tahun 2009 tentang Kekuasaan Kehakiman, UU Nomor 3 Tahun 2009 Tentang Mahkamah Agung, Peraturan Mahakamah Agung Nomor 2 Tahun 2019 Tentang Pedoman Penyelesaian Sengketa Tindakan Pemerintahan dan Kewenangan Mengadili Perbuatan Melanggar Hukum Oleh Badan dan/atau Pejamat. Bahan hukum sekunder beberapa bahan pustaka baik dalam bentuk jurnal, buku hukum dan lain-lain, yang mengandung penjelasan tentang kewenangan lembaga pengadilan untu mengadili suatu perkara yang berdasarkan kompetensinya. Terutama mengenai kompetensi peradilan umum dan peradilan Tata Usaha Negara, serta bahan hukum tersier, yang merupakan bentuk data

\footnotetext{
${ }^{4}$ Soerjono Soekanto, Pengantar Penelitian Hukum, UI Press, Jakarta, 2010
}

penunjang seperti Kamus hukum dan kamus bahasa indonesia, ataupun kamus bahasa asing lainnya.

\section{PEMBAHASAN}

Pada dasarnya setiap manusia kecenderungannya membutuhkan ketertiban dan keadilan. Untuk itu dalam setiap kehidupan masyarakat selalu memunculkan penomena hukum yang berdampak pada setiap kebijakan hukum oleh para pemangku kebijakan, setiap kebijakan hukum tersebut pasti mempunyai kelemahan dan kekurangan sehingga ada yang merasa diuntungkan dan tidak sedikit yang merasa dirugikan.

Dinamika hukum merupakan sebuah keniscayaan yang terjadi dalam negara demokrasi, karena dinamika hukum yang plural juga dapat membentuk sistem hukum dalam masyarakat. Fungsi hukum adalah untuk dikondisikan dan juga mengkondisikan masyarakat, sehingga tujuan utama diciptakannya hukum pada dasarnya untuk mewujudkan ketertiban dan keadilan.

Menurut B. Arief Sidarta, masyarakat bagaimanapun bentuk kesederhanaannya selalu membutuhkan penataan dan pengaturan prilaku yang dalam penegakannya tidak dapat sepenuhnya diserahkan kepada kebebasan masingmasing. Oleh karenanya di dalam kehidupan masyarakat dibutuhkan sistem pengendalian sosial (social cotrol) terhadap prilaku masyarakat tersebut, sistem pengendalian masyarakat yang berjalan dalam segala kehidupan telah mengalami berbagai perubahan dan memunculkan berbagai sistem hukum, dalam menjalankanya sistem hukum tersebut tidak dapat diserahkan sepenuhnya kepada kemauan bebas setiap individu warga masyarakat, akan tetapi dalam pelaksanaannya dapat dipaksakan secara terorganisasi secara politik yang 
berbentuk badan hukum publik yang disebut dengan Negara. ${ }^{5}$

Menurut Gustav Radbruch, tujuan hukum adalah Kepastian, menurutnya hukum tersebut akan mempunyai kepastian apabila sudah dipositifkan atau disebut dengan hukum positif ${ }^{6}$ Kepastian hukum mempunyai dua pengertian yaitu kepastian oleh karena hukum dan kepastian dalam hukum itu sendiri. Hukum yang menjamin kepastian dalam hubungan kemasyarakatan adalah hukum yang berguna. Kepastian dalam hukum bisa tercapai apabila peraturan Perundang-Undangan di dalamnya tidak terdapat keterangan-keterangan yang bertentangan dan tidak terdapat istilah-istilah yang dapat ditafsirkan secara berlainan. ${ }^{7}$ Tentunnya kepastian hukum hanya dapat ditegakkan oleh lembaga yudisial (Pengadilan) yang kekuasaannya lebih tinggi, seperti Mahkamah Agung fungsinya untuk mengatur lembaga Peradilan dibawahnya supaya tertib hukum dapat tercapai, yang di dalam penegakannya dijalankan oleh para Hakim yang mempunyai kemerdekaan dan Kekuasan yang telah dijamin oleh UndangUndang.

\section{Pengertian Kekuasaan Kehakiman}

Dalam penjelasan umum UUD 1945 menegaskan bahwa Indonesia adalah negara hukum (rechtstaad) bukan negara kekuasaan (maachstaad). Sejalan dengan ketentuan tersebut salah satu prinsip penting negara hukum adalah adanya kebebasan penyelenggaraan kekuasaan kehakiman yang merdeka, sehingga dalam pasal 24 ayat (1) UUD 1945 berbunyi :

"Kekuasaan Kehakiman merupakan kekuasaan yang merdeka untuk

${ }^{5}$ B. Arief Sidarta, "Hubungan antara ilmu hukum, teori hukum dan filsafat hukum dalam Pro justitia Tahun XX. Alumni FH UNFAR, Bandung 2002, hal. 3

${ }^{66}$ Krisnajadi, Pengantar IImu Hukum Bagian I, Sekolah Tinggi Ilmu Hukum, Bandung, 1989, hal. 60

7 E. Utrech dalam Saleh Djindang, Pengantar Dalam Hukum Indonesia, Sinar Harapan, Jakarta 1989, hal. 13 menyelenggarakan peradilan guna menegakkan hukum dan keadilan.".

Dalam pasal (1) Undang-Undang Nomor 4 Tahun 2004 tentang Kekuasaan Kehakiman, berbunyi "Kekuasaan Kehakiman adalah kekuasaan negara yang merdeka untuk menyelenggarakan peradilan guna menegakkan hukum dan keadilan berdasarkan pancasila demi terselenggaranya Negara Hukum Republik Indonesia". ${ }^{8}$

Lebih lanjut juga dijelaskan dalam Undang-Undang Kekuasaan kehakiman yaitu UU No. 48 Tahun 2009, dalam perkembangannya tidak jauh berbeda dengan UU sebelumnya, hanya saja dalam UU sebelumnya kurang begitu tegas karena tidak mencantumkan UUD 1945 sebagai landasan konstitusionalnya, sehingga di dalam UU Nomor 48 Tahun 2009 mencantumkan landasan penegakan hukum ada dua yaitu : Dasar Negara (Pancasila) dan landasan Konstitusional adalah UUD 1945, sehingga setelah disempurnakan dasar penegakan hukum di Indonesia adalah pancasila dan UUD 1945. Selanjutnya dalam pasal (1) UU No. 48 Tahun 2009 sudah di pertegas, sehingga berbunyi :9

"Kekuasaan Kehakiman adalah

kekuasaan Negara yang merdeka untuk menjalankan peradilan guna menegakkan hukum dan keadilan berdasarkan Pancasilan dan Undangundang Dasar Negara Republik Indonesia Tahun 1945, demi terselnggaranya Negara Hukum Republik indonesia."

Menurut ajaran Montesquiieu, bahwa dalam paradigma Positivisme hukum, undang-undang atau keseluruhan peraturan perundang-undangan dipikirkan sebagai sesuatu yang memuat hukum secara lengkap sehingga tugas hakim hanya menerapkan ketentuan undang-undang secara mekanis dan linier untuk menyelesaikan

\footnotetext{
8 Republik Indonesia, UU No. 4 Tahun 2004 tentang Kekuasaan Kehakiman

${ }^{9}$ Republik Indonesia, UU No. 48 Tahun 2009 tentang Kekuasaan Kehakiman
} 


\begin{abstract}
permasalahan masyarakat. ${ }^{10}$ Dengan demikian seorang hakim dalam memutus suatu sengketa yang diadilinya tidak dapat lepas dari segala peraturan yang sudah ditetapkan dalam bentuk peraturan perundang-undangan. Dalam menjalankan fungsinya seorang hakim harus merdeka, sehingga penegakan hukum dapat di jalankan secara berkeadilan dan tidak keluar dari peraturan-peraturan hukum yang telah digariskan.

Berdasarkan ajaran positivisme hukum segala kehidupan bernegara dan bermasyarakat tunduk pada the rule of law, dalam arti negara dan masyarakat diatur dan diperintah oleh hukum, bukan diperintah oleh kediktatoran penguasa secara membabi buta. Peran Rule of law dalam tata kehidupan berbangsa dan bernegara menjadi landasan tata tertib kehidupan untuk menghindari pemerkosaan hukum terhadap hak-hak setiap warganegara dalam bentuk apapun, termasuk di dalam dunia Peradilan.
\end{abstract}

\section{Batasan Kewenangan Mengadili Peradilan Umum dan Peradilan Tata Usaha Negara (TUN) Dalam Perkara Perbuatan Melawan Hukum}

Keberadaan lembaga pengadilan dibentuk, agar dapat menuntaskan segala perkara yang timbul diantara para pihak yang berperkara sehingga tercipta rasa keadilan. Sengketa yang timbul berbagai macam ragamnya, ada sengketa wanprestasi yang berkaitan dengan perjanjian (breach of contract), perbuatan melawan hukum (onrechtmatige daad), sengketa kekayaan intelektual (property right), sengketa kepailitan, sengketa perceraian, sengketa penyalahgunaan wewenang oleh penguasa, dan lain sebagainya. Semua perkara atau sengketa tidak dapat di monopoli oleh satu

10 Widodo Dwi Putro, Kritik Terhadapa paradigma Positivisme Hukum, Genta Publishing, yogyakarta 2011, hal. 1 bentuk lapangan pengadilan, keberadan sengketa-sengketa tersebut kalau selalu di hubungkam dengan peradilan perdata misalnya merupakan monopoli yurisdiksi Peradilan Umum, tentunya kalau tidak diatur dengan tegas akan menimbulkan permasalahan tentang kekuasaan mengadili kalau dipaksakan. ${ }^{11}$

Salah satu faktor pembagian yurisdiksi pengadilan adalah berdasarkan lingkungan pengadilan, dengan jelasnya lingkungan pengadilan tersebut akan melahirkan kekuasaan mengadili atau kewenangan absolut masing-masing lingkungan pengadilan yang disebut sebagai atribusi kekuasaan kehakiman (attributive competentie, attributive jurisdiction). ${ }^{12}$ Seperti lingkungan Peradilan Umum dan lingkungan Peradilan Tata Usaha Negara, ataupun lingkungan lembaga peradilan lainnya.

Dasar hukum lahirnya peradilan umum adalah Undang-Undang No. 2 tahun 1986 yang kemudian diubah oleh UU No. 8 tahun 2004 tentang peradilan umum. Kemudian UU No. 8 tahun 2004, diubah menjadi UU No. 49 Tahun 2009 tentang peradilan Umum. Peradilan umum adalah salah satu bentuk kekuasaan kehakiman bagi rakyat pada umumnya. Kekuasaan kehakiman di lingkungan peradilan umum dilaksanakan oleh Pengadilan Negeri sebagai pengadilan tingkat pertama dan Pengadilan tinggi sebagai pengadilan tingkat banding, kemudian puncaknya pada Mahkamah Agung sebagai pengadilan yang tertinggi atau sebagai pengadilan tingkat kasasi.

Sedangkan dasar hukum lahirnya pengadilan Tata Usaha Negara adalah UU No. 5 Tahun 1986, yang kemudian selanjutnya diubah dengan UU No. 9 Tahun 2004 tentang Peradilan Tata Usaha Negara. UndangUndang ini kemudian diubah menjadi UU No.

11 M. Yahya harahap dalam terence Ingman, Hukum Acara Perdata tentang Gugatn, Persidangan, Penyitaan, Pembuktian, dan Putusan Pengadilan,Sinar Grafika, Jakarta, 2004. Hal. 179

12 Subekti, Hukum Acara perdata, Bina Cipta, Jakarta, 1977, hal. 28 
51 tahun 2009 tentang Peradilan Tata Usaha Negara. Dalam Pasal 4 UU No. 51 Tahun 2009, berbunyi : 'Peradilan Tata Usaha Negara Adalah salah satu pelaksana Kekuasaan Kehakiman bagi Rakyat pencari keadilan terhadap sengketa Tata Usaha Negara."

Yang dimaksud sengketa Tata Usaha Negara adalah sengketa yang timbul dalam bidang Tata Usaha Negara antara orang atau badan hukum perdata dengan Badan atau Pejabat Tata Usaha Negara. Kekuasan Kehakiman di lingkungan Tata Usaha Negara secara hierarki dilaksanakan oleh Pengadilan Tata Usaha Negara, Pengadilan Tinggi Tata Usaha Negara, dan Mahkamah Agung (MA). ${ }^{13}$

Dari pembagian lingkungan peradilan tersebut dalam praktek beracara di pengadilan sering terjadi kekaburan dalam menentukan batas yang jelas tentang yurisdiksi absolut, terutama antara Peradilan Umum, Peradilan Agama atau Peradilan Tata Usaha Negara (TUN). Dalam praktik, Peradilan Tata Usaha Negara dan Peradilan Umum sering terjadi titik singgung, sehingga sulit sekali menentukan batasan yang lengkap mengenai keputusan Tata Usaha Negara dan yang mana yang bukan merupakan keputusan Tata Usaha Negara. Karena masih seringnya terjadi permasalahan titik singgung kompetensi antara PERATUN dan Peradilan Umum tersebut, merupakan problematik tersendiri yang perlu terlebih dahulu dipecahkan sebelum hakim memeriksa perkara. ${ }^{14}$

Berikut kewenangan masing-masing lingkungan lembaga peradilan adalah sebagai berikut :

1. Peradilan umum sebagaimana yang digariskan pasal 50 dan pasal 51 UU No. 2 Tahun 1986 tentang peradilan umum, hanya berwenang mengadili perkara Pidana (pidana umum dan pidana khusus, mengadili perkara

\footnotetext{
${ }^{13}$ Umar said Sugiarto, Pengantar Hukum Indonesia, Sinar Grafika, Malang, 2012. Hal. 107

14 lbid. Hal. 182
}

perdata (Perdata Umum dan Perdata Niaga);

2. Peradilan agama berdasarkan pasal 49 UU No. 7 Tahun 1989 tentang Peradilan agama, hanya berwenang mengadili perkara bagi rakyat yang beragama Islam, mengenai Perkawinan, kewarisan (meliputi wasiat, hibah yang dilakukan berdasarkan hukum islam). Wakaf dan Sadakah;

3. Peradilan Militer, sesuai dengan ketentuan pasal 40 UU No. 31 Tahun 1997, hanya berwenang mengadili perkara pidana yang terdakwanya terdiri dari prajurit TNI berdasarkan pangkat tertentu.

4. Yang berikutnya adalah Pengadilan Tata Usaha Negara (TUN), yurisdiksinya hanya terbatas pada perkara-perkara melibatkan Lembaga Negara yang berkaitan dengan kebijakan administrasi negara.

Memperhatikan uraian diatas, kalau ditinjau dari segi pembagian Kekuasaan Kehakiman, Undang-Undang telah menentukan batasan yurisdiksi masingmasing lembaga pengadilan. Sengketa yang dapat diajukan ke Pengadilan Negeri (PN) dalam hal ini kedudukannya sebagai peradilan umum, hanya terbatas pada perkara pidana dan perkara perdata, dalam bidang perdata terbatas pada Perdata Umum dan Perdata Niaga, sedangkan perkara perdata lain mengenai perkawinan dan warisan bagi yang beragama Islam menjadi yurisdiksi absolud lingkungan Peradilan Agama. Sedangkan untuk Perkara Perdata Tata Usaha Negara (TUN) merupakan juridiksi Peradilan Tata Usaha Negara.

\section{Penetapan Kewenangan Mengadili Pengadilan Negeri dan Pengadilan Tata Usaha Negara (TUN) Dalam Perkara Perbuatan Melawan Hukum Yang Melibatkan Badan Atau Pejabat Negara (Onrechtmatige}




\section{Overheidsdaad) Menurut PERMA Nomor 2 Tahun 2019}

Salah satu kewenangan dari Mahkamah Agung yang diamanatkan oleh konstitusi adalah sebagai Pelaksana Kekuasaan Kehakiman yaitu menguji peraturan perundang-undangan di bawah undangundang. Tujuan utama pemberian hak menguji kepada Mahkamah Agung terhadap peraturan perundang-undangan merupakan salah satu bentuk fungsinya dalam melaksanakan kekuasaan kehakiman, dengan tujuan untuk melakukan pengawasan terhadap semua tindakan pemerintah atau penguasa.

Kewenangan hak uji yang diberikan Konstitusi Negara (UUD 1945) kepada Mahkamah Agung (MA) terhadap peraturan perundang-undangan ditegaskan dalam Pasal 24A ayat (1) UUD 1945, yang berbunyi : ${ }^{15}$

"Mahkamah Agung berwenang
mengadili pada tingkat kasasi,
menguji peraturan perundang-
undangan di bawah Undang-Undang
terhadap Undang-Undang"

Selanjutnya kewenangan yang diberikan kepada Mahkamah Agung tentang hak uji tersebut lebih lanjut dipertegas lagi berdasarkan ketentuan Pasal 24A UUD 1945 juncto Pasal 11 ayat (2) huruf (b) UU No. 48 Tahun 2009 tentang Kekuasaan Kehakiman juncto Pasal 31 ayat (1) dan ayat (2) UU No. 3 Tahun 2009 tentang Mahkamah Agung, bahwa pasal-pasal tersebut mengamanatkan Mahkamah Agung-RI mempunyai kewenangan menguji undang-undang berupa "hak uji materiil" maupun "hak Uji Formil" terhadap peraturan perundang-undangan di bawah undang-undang terhadap undangundang."

Berkaitan dengan Hak Uji Mahkamah Agung (MA) tersebut, lebih lanjut dipertegas lagi dalam pasal 31 ayat (2) Undang-Undang

${ }^{15}$ RepubliK indonesia, UUD 1945 Pasal 24A ayat (1)
Nomor : 3 Tahun 2009 tentang Mahkamah Agung, berbunyi : ${ }^{16}$

"Mahkamah Agung menyatakan tidak sah peraturan perundang-undangan di bawah undang-undang atas alasan bertentangan dengan peraturan perundang-undangan yang lebih tinggi atau pembentukannya tidak memenuhi ketentuan yang berlaku."

Hak Uji Materil (materiel judicial review atau materiele toetsingsrect) oleh Mahkamah Agung adalah kewenangan Mahkamah Agung menguji atau menilai materi muatan dalam ayat, pasal, dan/atau bagian peraturan perundang-undangan di bawah undangundang jika bertentangan dengan peraturan perundang-undangan yang lebih tinggi. Sedangkan hak uji Formil (formal judicial review atau formele totsingsrecht) oleh Mahkamah Agung adalah kewenangn mahkamah Agung menguji atau menilai prosedur dan kewenangan pembentukan peraturan perundang-undangan di bawah undang-undang apakah sudah memenuhi syarat atau sesuai dengan tata cara pembentukan peraturan perundangundangan yang berlaku. ${ }^{17}$

Disamping Kekuasaan yang dimiliki oleh Mahkamah Agung di dunia peradilan. Seperti uraian sebelumnya, bahwa selain Mahkamah Agung juga berperan sebagai lembaga yang berhak menguji peraturan perundangundangan dibawah undang-undang, kemudian Mahkamah Agung juga diberikan kewenangan penuh oleh Undang-Undang untuk dapat menciptakan peraturanperaturan yang dianggap penting apabila terjadi kekosongan hukum dalam penegakannya, dengan tujuan agar supaya tidak terjadi kekaburan norma. Salah satu hak Mahkamah Agung yang diberikan oleh undang-undang untuk mengisi kekosongan hukum atau kekaburan norma tersebut adalah dengan mengeluarkan Peraturan

\footnotetext{
16 Republik Indonesia, Undang-Undang No. 3 Tahun 2009 tentang Mahkamah Agung

17 Umar Sadi sugiarto, Op.Cit. hal. 57 - 58
} 
Mahkamah Agung atau disingkat dengan PERMA.

Kedudukan Peraturan Mahkamah Agung (PERMA) dalam tata urutan aturan hukum di Indonesia diatur dalam Undang-Undang Nomor 14 tahun 1985 tentang Mahkamah agung juncto Undang-Undang Nomor 3 Tahun 2009 tentang Mahkamah Agung. Dalam pasal 79 Undang-Undang Nomor 14 tahun 1985 tentang Mahkamah Agung (UUMA), berbunyi: ${ }^{18}$

"Mahkamah Agung dapat mengatur lebih lanjut hal-hal yang diperlukan bagi kelancaran penyelenggaraan peradilan apabila terdapat hal-hal yang belum cukup diatur dalam undang-undang ini."

Menurut Undang-Undang Nomor 14 Tahun 1985 tersebut keberadaan PERMA berperan untuk mengisi kekosongan hukum terhadap materi hukum yang belum diatur di dalam Undang-Undang. Jadi yang perlu di garis bawahi batasan pertama adalah materi yang terkandung di dalam PERMA adalah Materi yang belum diatur di dalam UndangUndang. Batasan kedua adalah materi yang terkandung di dalam PERMA tersebut adalah tentang penyelenggaraan peradilan yang berkaitan dengan Hukum Acara.

Dalam teori hukum, dengan adanya PERMA maka dianggap sebagai langkah yang progresif, karena dianggap mampu melakukan terobosan hukum. Dengan terobosan hukum tersebut merupakan salah satu solusi mengisi kekosongan hukum, seperti terobosan yang dilakukan dengan langkah mengeluarkan PERMA Nomor 2 Tahun 2019 tentang Pedoman Penyelesaian Sengketa Tindakan Pemerintah dan Kewenangan Mengadili Perbuatan melanggar hukum Oleh Badan/Atau Pejabat Pemerintah (Onrechtmatige Overheidsdaad).

18 Republik Indonesia, Undang-Undang Nomor 14 Tahun 1985 tentang Mahkamah Agung
Dalam PERMA Nomor 2 Tahun 2019 pada "Hal" menimbang huruf (b), berbunyi $: 19$

"bahwa perbuatan melawan hukum oleh Badan dan/atau pejabat Pemerintah (Onrechtmatige Overheidsdaad) merupakan tindakan pemerintah sehingga menjadi kewenangan Peradilan Tata Usaha Negara berdasarkan undangUndang Nomor 30 Tahun 2014 tentang Administrasi Pemerintahan."

Kenapa dipertegas seperti diatas ?, dikarenakan mengingat di dalam ketentuan Peralihan Undang-Undang Nomor 30 Tahun 2014 tentang Administrasi Pemerintahan, ternyata tidak menyebutkan secara rinci tentang yurisdiksi pengadilan terutama mengenai batasan kompetensi absolud PERATUN dalam menangani perkara-perkara perdata yang melibatakan badan atau Pejabat pemerintahan, sehingga oleh Mahkamah Agung (MA), Untuk mengaturnya secara tegas dan bersifat khusus (/ex specialist), diterbitkanlah PERMA No. 2 Tahun 2019.

Dalam pasal 1 ayat (1), ayat (2), ayat (3), ayat (4) PERMA No. 2 Tahun 2019, berbunyi $^{20}$

(1) Tindakan Pemerintahan adalah Perbuatan Pejabat Pemerintah atau penylemggara negara lainnya untuk melakukan dan/atau tidak melakukan perbuatan konkret dalam rangka penyelenggaraan pemerintahan.

(2) Pejabat pemerintahan adalah unsur yang melaksanakan Fungsi Pemerintahan baik di lingkungan pemerintah maupun penyelenggara negara lainnya.

(3) Sengketa tindakan pemerintah adalah sengketa yang timbul dalam bidang administrasi pemerintahan

\footnotetext{
19 Republik Indonesia, PERMA Nomor 2 Tahun 20019, dalam hal menimbang hurup (b)

${ }^{20}$ Republik indonesia, Perma Nomor 2 tahun 2019,Pasal 1 ayat (1), ayat (2), ayat (3), ayat (4)
} 
antara Warga masyarakat dengan

Pejabat Pemerintahan atau Penyelenggara negara lainnya sebagai akibat dilakukannya Tindakan Pemerintah.

(4) Sengketa Perbuatan Melanggar Hukum oleh Badan dan/atau Pejabat Pemerintah (Onrechtmatige Overheidsdaad) adalah sengketa yang di dalamnya mengandung tuntutan untuk menyatakan tidak sah dan/atau batal tindakan Pejabat Pemerintah, atau tidak mempunyai kekuatan hukum mengikat beserta ganti rugi sesuai dengan ketentuan peraturan perundang-undangan.

Lebih lanjut dijelaskan, ketentuan peraturan mengenai kewenangan mengadili Peradilan Tata Usaha Negara (TUN) tentang perkara administrasi negara berkaitan dengan tindakan pejabat pemerintah tersebut secara tegas di jabarkan oleh PERMA No. 2 Tahun 2019 dalam Pasal (2) ayat (1), ayat (2), dan ayat (3), berbunyi : ${ }^{21}$

(1) Perkara Perbuatan melangga hukum oleh Badan dan/atau Pejabat Pemerintahan (Onrechtmatige Overheidsdaad) merupakan Kewenangan Peradilan Tata Usaha Negara.

(2) Pengadilan Tata Usaha Negara berwenang mengadili Sengketa Tindakan Pemerintah setelah menempuh upaya administratif sebagaimana dimaksud dalam Undang-Undang Nomor 30 Tahun 2014 tentang administrasi Pemerintahan dan Peraturan Mahkamah Agung Nomor 6 Tahun 2018 tentang Pedoman Penyelesaian Administrasi Pemerintahan Setelah Menempuh upaya Administratif.

(3) Dalam hal peraturan perundangundangan mengatur secara

21 Republik Indonesia, PERMA Nomor 2 Tahun 2019, Pasal 2 ayat (1), ayat (2), ayat (3) khusus upaya administratif maka yang berwenang mengadili Sengketa Tindakan Pemerintah adalah Pengadilan Tinggi Tata Usaha Negara sebagai Pengadilan tingkat Pertama.

Mengenai ketentuan yang berkaitan dengan kompetensi absolut lembaga peradilan dalam hal ini antara Pengadilan Negeri dan Pengadilan Tata Usaha Negara, maka secara tegas di atur pada bagian Ketentuan Penutup PERMA Nomor 2 Tahun 2009. Ketentuan Penutup tersebut tercantum di dalam Bab V PERMA Nomor 2 Tahun 2009 yaitu terdapat pada pasal (10), Pasal (11) dan Pasal (12), berbunyi sebagai berikut : ${ }^{22}$

(1) Pasal 10 :

"Pada saat Peraturan mahkamah Agung ini mulai berlaku, perkara perbuatan melanggar hukum oleh Badan dan/atau Pejabat Pemerintah (Onrechtmatige Overheidsdaad) yang diajukan ke Pengadilan Negeri tetap belum diperiksa, dilimpahkan kepada Pengadilan Tata Usaha Negara sesuai dengan ketentuan peraturan perundang-undangan."

(2) Pasal 11

Perkara Perbuatan Menggar hukum oleh Bada dan/atau Pejabat Pemerintah (Onrechtmatige Overheidsdaad) yang sedang diperiksa oleh Pengadilan Negeri, Pengadilan Negeri harus menyatakan tidak berwenang mengadili.

(3) Pasal (12)

Perkara perbuatan melanggar hukum oleh Badan dan/atau

22 Republik indonesia, PERMA Nomor 2 Tahun 2019, Pasal 10, Pasal 11, Pasal 12 


Pejabat Pemerintah
(Onrechtmatige Overheidsdaad)
sebagaimana dimaksud Pasal 10
yang upaya administratifnya telah
diatur secara khusus pada saat
Peraturan Mahkamah Agung ini di
Undangkan, telah dilimpahkan oleh
Pengadilan Negeri ke Pengadilan
Tata Usaha Negara dan belum
diperiksa oleh Pengadilan Tata
Usaha Negara, berkas perkara
dilimpahkan ke Pengadilan Tinggi
Tata Usaha Negara yang
berwenang disertai sisa panjar
biaya perkaranya.

Dalam penulisan penelitian ini tentunya secara khusus menyoroti langkah terobosan hukum yang dilakukan oleh Mahkamah Agung dengan terbitnya PERMA No. 2 Tahun 2019, sehingga dengan langkah terobosan hukum tersebut dapat memecahkan segala kebuntuan hukum sekaligus dapat memberikan manfaat dalam penegakan hukum acara secara progresif, karena dengan peraturan yang jelas tersebut tidak ada lagi perkara-perkara administrasi pemerintahan yang melibatkan Badan dan/atau Pejabat Pemerintahan akan diperiksa oleh peradilan umum (Pengadilan Negeri) karena merupakan Kompetensi absolud dari lapangan Pengadilan Tata Usaha Negara (TUN).

\section{KESIMPULAN}

1. Batasan Kewenangan Mengadili Peradilan Umum Dan Peradilan Tata Usaha Negara (TUN) Dalam Perkara Perbuatan Melawan Hukum, yaitu :

a. Peradilan umum adalah salah satu bentuk kekuasaan kehakiman bagi rakyat pada umumnya. Kekuasaan kehakiman di lingkungan peradilan umum dilaksanakan oleh Pengadilan Negeri sebagai pengadilan tingkat pertama dan Pengadilan tinggi sebagai pengadilan tingkat banding,

kemudian puncaknya pada
Mahkamah Agung sebagai
pengadilan yang tertinggi atau
sebagai pengadilan tingkat kasasi.
Peradilan umum sebagaimana yang
digariskan pasal 50 dan pasal 51 UU
No. 2 Tahun 1986 tentang peradilan
umum, hanya berwenang mengadili
perkara Pidana (pidana umum dan
pidana khusus, mengadili perkara
perdata (Perdata Umum dan Perdata
Niaga);

b. Yang dimaksud sengketa Tata Usaha Negara adalah sengketa yang timbul dalam bidang Tata Usaha Negara antara orang atau badan hukum perdata dengan Badan atau Pejabat Tata Usaha Negara. Kekuasan Kehakiman di lingkungan Tata Usaha Negara secara hierarki dilaksanakan oleh Pengadilan Tata Usaha Negara, Pengadilan Tinggi Tata Usaha Negara, dan Mahkamah Agung (MA). Pengadilan Tata Usaha Negara (PERATUN), merupakan pengadilan Khusus yang yurisdisksinya hanya terbatas mengadili perkara-perkara yang melibatkan Badan Negara ataupun Pejabat Pemerintahan apabila dilibatkan dalam perkara perdata Tata Usaha Negara,

2. Kewenangan absolut Pengadilan Tata Usaha Negara (TUN) Dalam Perkara Perbuatan Melawan Hukum Yang Melibatkan Badan Atau Pejabat Negara (Onrechtmatige Overheidsdaad), tidak dapat diadili oleh pengadilan Negeri, secara keseluruhan telah diatur dalam PERMA Nomor : 2 Tahun 2019. Ketentuan tersebut tercantum di dalam Bab V, yaitu terdapat pada pasal (10), Pasal (11) dan Pasal (12), berbunyi sebagai berikut :23

\footnotetext{
${ }^{23}$ Republik Indonesia, PERMA Nomor 2 Tahun 2019
} 
Pasal 10 :

DAFTAR PUSTAKA

"Pada saat Peraturan mahkamah Agung ini mulai berlaku, perkara perbuatan melanggar hukum oleh Badan dan/atau Pejabat Pemerintah (Onrechtmatige Overheidsdaad) yang diajukan ke Pengadilan Negeri tetap belum diperiksa, dilimpahkan kepada Pengadilan Tata Usaha Negara sesuai dengan ketentuan peraturan perundang-undangan."

Pasal 11

Perkara Perbuatan Menggar hukum oleh Bada dan/atau Pejabat Pemerintah (Onrechtmatige Overheidsdaad) yang sedang diperiksa oleh Pengadilan Negeri, Pengadilan Negeri harus menyatakan tidak berwenang mengadili.

Pasal (12)

Perkara perbuatan melanggar hukum oleh Badan dan/atau Pejabat Pemerintah (Onrechtmatige Overheidsdaad) sebagaimana dimaksud Pasal 10 yang upaya administratifnya telah diatur secara khusus pada saat Peraturan Mahkamah Agung ini di Undangkan, telah dilimpahkan oleh Pengadilan Negeri ke Pengadilan Tata Usaha Negara dan belum diperiksa oleh Pengadilan Tata Usaha Negara, berkas perkara dilimpahkan ke Pengadilan Tinggi Tata Usaha Negara yang berwenang disertai sisa panjar biaya perkaranya.

\section{A. Buku- Buku}

B. Arief Sidarta, "Hubungan antara ilmu hukum, teori hukum dan filsafat hukum dalam Pro justitia Tahun XX. Alumni $\mathrm{FH}$ UNFAR, Bandung 2002,

Krisnajadi, Pengantar IImu Hukum Bagian I, Sekolah Tinggi Ilmu Hukum, Bandung, 1989,

M. Yahya harahap, Hukum Acara Perdata tentang Gugatn, Persidangan, Penyitaan, Pembuktian, dan Putusan Pengadilan,Sinar Grafika, Jakarta, 2004.

Kekuasaan

Mahkamah Agung, Pemeriksaan kasasi dan Peninjauan kembali Perkara Perdata,SinarGrafika, Jakarta, 2007

Saleh Djindan, Pengantar Dalam Hukum Indonesia, Sinar Harapan, Jakarta 1989.

Subekti, Hukum Acara perdata, Bina Cipta, Jakarta, 1977

Soerjono Soekanto, Pengantar Penelitian Hukum, UI Press, Jakarta, 2010

Umar said Sugiarto, Pengantar Hukum Indonesia, Sinar Grafika, Malang, 2012

Widodo Dwi Putro, Kritik Terhadapa paradigma Positivisme Hukum, Genta Publishing, yogyakarta 2011

\section{B. Peraturan Perundang-Undangan}

Republik Indonesia, Undang - Undang Dasar Tahun 1945

Republik Indonesia, Undang Undang Nomor 48 Tahun 2009, tentang Kekuasaan Kehakiman 


Republik Indonesia, Undang Undang
Nomor 3 Tahun 2009, tentang
Mahkamah Agung
Republik Indonesia, Undang Undang
Nomor 49 Tahun 2009, tentang
Peradilan Umum
RepublikIndonesia, Undang Undang
No. 51 tahun 2009 tentang
Peradilan Tata Usaha
Republik Indonesia, Peraturan
Mahakamah Agung Nomor 2
Tahun 2019, Tentang Pedoman
Penyelesaian Sengketa
Tindakan Pemerintahan dan
Kewenangan Mengadili
Perbuatan Melanggar Hukum
Oleh Badan dan/atau Pejamat
Pemerintah (Onrechtmatige
Overheidsdaad)

